\title{
Amoniasi Daun Kelapa Sawit Dengan Beberapa Taraf Urea Dan Pengaruhnya Terhadap Kandungan Gizi Dan Kecernaan Secara In Vitro
}

\author{
Mardiati Zain, Erpomen dan Kartini \\ Program Studi Nutrisi dan MakananTernak Fakultas Peternakan Universitas Andalas \\ Kampus Unand Limau Manis 25163
}

\begin{abstract}
An experiment was conducted to evaluate the effect of ammoniation on the digestibility of oil palm frond. As treatments, oil palm frond was mixed with difference levels of urea of 0, 3, 6 and $9 \%$ of DM basis. The mixtures were then added $15 \%$ dried chicken manure and the incubated in anaerobic condition for one week. Parameters measured included: fiber fractions content and digestibility of $D M$ and $O M$. Data were statistically analyzed by variance analysis in a block randomized design. Results showed that the treatments gave significant effect on the digestibility. Digestibility of DM and OM of oil palm frond treated with 6 and $9 \%$ urea were higher than that of treated with 0 and $3 \%$ of urea. The best digestibility was found by ammoniation with $6 \%$ urea.
\end{abstract}

Key words: Oil palm frond, ammoniation, in vitro digestion.

\section{Pendahuluan}

Ternak ruminansia merupakan salah satu jenis ternak yang mampu memberikan kontribusi yang besar untuk kesejahteraan manusia melalui produksi susu, daging dan produk sampingan lainnya. Salah satu faktor yang sangat menentukan kemajuan suatu usaha peternakan ruminansia adalah ketersediaan rumput sebagai makanan utama. Kecenderungan akhir = akhir ini ketersediaan rumput semakin sulit dikarenakan berkurangnya alokasi lahan untuk tanaman pakan ternak, dikarenakan terjadinya peningkatan penggunaan lahan untuk pemukiman, industri dan perkebunan. Untuk itu perlu dicari bahan pakan hijauan alternatif yang bisa menggantikan rumput.

Bahan pakan alternatif pengganti rumput seyogyanya tersedia dalam satu tempat dalam jumlah yang banyak dan tersedia terus menerus.
Berbagai hasil ikutan pertanian ataupun perkebunan dapat dijadikan sebagai sumber baru bahan makanan ternak. Perkebunan kelapa sawit sekarang di Indonesia menjadi primadona dan dari tahun ketahun terjadi peningkatan luas areal yang cukup tinggi. Menurut Fauzi et al, (2006) selama tahun 1990-2000 luas perkebunan kelapa sawit berkembang cukup pesat dimana luas areal perkebunan sawit pada tahun 1990 yang hanya 8,5 juta $\mathrm{Ha}$ menjadi 14,2 juta hektar ditahun 2000. Meningkatnya luas perkebunan akan menyebabkan juga peningkatan limbah yang dihasilkan.

Dari seluruh produksi tandan buah sawit hanya sekitar 22,1 \% berupa hasil utama (minyak sawit 20 $\%$ dan minyak inti sawit $2,1 \%$ ). Sekitar 2,2 \% berupa hasil ikutan (bungkil inti sawit) dan selebihnya $(75,7 \%)$ berupa limbah seperti tandan buah kosong, serat sawit dan lain - 
lain. Disamping tandan kosong sawit, daun sawit juga potensial dijadikan sebagai pakan ternak ruminansia pengganti hijauan. Daun kelapa sawit mirip daun kelapa yaitu membentuk susunan daun majemuk, bersirip genap dan bertulang sejajar. Jumlah anak daun disetiap pelepah berkisar antara 250 - 400 helai. Dari satu hektar lahan diperkirakan dapat dihasilkan 6500 - 7500 pelepah pertahun (Hassan dan Ishida, 1991). Kandungan gizi daun sawit yaitu $54,12 \%$ bahan kering, $8,51 \%$ protein kasar, 59,11 \% NDF, 42,87 \% ADF, $24,69 \%$ selulosa dan $12,90 \%$ lignin, yang cukup potensial sebagai sumber energi bagi ternak ruminansia.

Penggunaan daun kelapa sawit dalam pakan telah dicobakan pada sapi pedaging dan sapi perah, namun daun kelapa sawit ini hanya bisa digunakan $30-40 \%$ pengganti rumput (Ishida dan Hassan, 1992).

Limbah atau hasil ikutan ini mempunyai keterbatasan dalam penggunaannya sebagai pakan antara lain bersifat amba dan mengandung serat kasar serta lignin yang tinggi. Oleh karena itu perlu dilakukan pengolahan sebelum diberikan pada ternak untuk meningkatkan fermentabilitasnya dalam rumen. Peningkatan fermentabilitas pakan berserat tinggi diupayakan dengan melakukan beberapa teknologi pengolahan seperti pengolahan secara kimia (perlakuan alkali dan amoniasi), perlakuan biologi (fermentasi dengan berbagai jenis mikroorganisme aerob atau anaerob) dan perlakuan fisik (penggilingan, pembuatan pellet, dan steam). Metode - metode tersebut sudah banyak dikaji dan telah memperlihatkan hasil yang cukup baik.
Salah satu teknik pengolahan yang cukup efektif meningkatkan kualitas limbah adalah perlakuan kimia menggunakan urea yang disebut amoniasi. Amoniasi dengan urea merupakan perlakuan kimia yang tergolong murah dan mudah dilakukan. Perlakuan amoniasi dengan urea pada pakan serat selain mampu melonggarkan ikatan lignoselulosa sehingga lebih mudah dicerna oleh bakteri rumen juga mampu memasok nitrogen untuk pertumbuhan bakteri tersebut (Leng, 1991)

Dari beberapa penelitian terbukti bahwa amoniasi dengan urea terhadap pakan serat mampu meningkatkan nilai manfaat dari pakan tersebut. Promma et al., (1985) menyatakan bahwa pemberian jerami padi yang diamoniasi dalam ransum sapi dapat meningkatkan pertambahan berat badan dan produksi susu. Van Soest (2006) melaporkan bahwa terjadi peningkatan konsumsi dan kecernaan bahan kering ransum jerami padi amoniasi dibanding yang tidak pada ternak sapi. Hal yang sama juga dilaporkan oleh Sundstol (1991) dimana terjadi peningkatan kecernaan bahan organik jerami padi amoniasi sebesar $13=18 \%$ pada ternak domba dan konsumsi bahan kering sebesar $45 \%$ pada ternak sapi dibanding yang tidak diamoniasi. Genin et al, (2007) menyatakan bahwa alfalfa yang diamoniasi dengan urea mempunyai kecernaan bahan kering, bahan organik NDF dan ADF yang lebih tinggi dibanding perlakukan menggunakan abu.

Penelitian ini ditujukan untuk mengetahui dosis urea yang tepat dalam proses amoniasi daun sawit sehingga didapatkan daun sawit fermentabel dalam rumen. 


\section{Metode Penelitian}

Daun kelapa sawit diambil dari perkebunan kelapa sawit di sekitar kota Padang. Daun sawit dibersihkan dari kotoran dan dipotong - potong sepanjang $5-10 \mathrm{~cm}$.

\section{Pembuatan Daun Sawit Amoniasi}

Daun sawit yang sudah đipotonng - potong masing - màsing sebanyak $1 \mathrm{~kg}$ diamoniasi dengan 0 , 3,6 , dan $9 \%$ urea dari bahan kering daun sawit. Urea untuk masing masing perlakuan dilarutkan dalam air bersih. Jumlah air yang digunakan adalah 1 : 1 dengan bahan kering daun sawit. Disamping urea untuk proses amoniasi ini juga ditambahkan kotoran ayam kering sebanyak $15 \%$ dari bahan kering daun sawit. Kotoran ayam dicampur merata pada daun sawit kemudian disemprot dengan larutan urea. Diaduk agar semua daun sawit kena oleh larutan urea. Kemudian daun sawit dimasukkan kedalam kantong plastik dipadatkan supaya suasana anaerob dan disimpan ditempat yang panas tapi teduh selama 1 minggu.

Setelah satu minggu kantong plastik dibuka, daun sawit dikeringkan/ dianginkan untuk menghilangkan bau amoniak setelah itu dikeringkan dan digiling. Untuk uji kualitas nutrisi, daun sawit yang sudah diamoniasi ini dikeringkan dalam oven $60 \mathrm{C}$ selama 48 jam dan selanjutnya dianalisis kan-dungan fraksi seratnya (Van Soest). Evaluasi kecernaan dilakukan dengan fermentasi secara in vitro dalam water shaker bath (Tilley and Terry, 1969).

Percobaan dilakukan dengan menggunakan Rancangan Acak Kelompok (RAK) 4 × 4 dimana terdapat 4 perlakuan (dosis urea 0,3 ,
6 , dan $9 \%$ BK daun sawit) dengan 4 kali ulangan. Pengaruh perlakukan terhadap peubah yang diukur dianalisis dengan anova. (Steel and Torrie, 1980).

\section{Hasil Dan Pembahasan}

\section{Kandungan Gizi dan Fraksi Serat dari Daun Sawit Amoniasi}

Kandungan fraksi serat dari daun sawit setelah diamoniasi dengan $0,3,6$, dan $9 \%$ urea disajikan pada Tabel 1. Dari tabel dapat dilihat bahwa dosis urea mampu mengubah komposisi kandungan gizi daun sawit. Kadar bahan organik terlihat sedikit meningkat pada daun sawit yang diamoniasi dibanding yang tidak diamoniasi. Hal ini dikarenakan penambahan kotoran ayam pada proses amoniasi akan meningkatkan kandungan bahan organik.

Dari Tabel 1 juga terlihat kandungan protein meningkat cukup tinggi dengan meningkatnya dosis urea. Ini sejalan dengan pendapat Leng (1991) yang menyatakan bahwa teknik amoniasi dapat meningkatkan kandungan protein kasar dari bahan yang diamoniasi disebabkan terfiksasinya nitrogen dari urea kedalam sel bahan. Kandungan fraksi serat dari daun sawit amoniasi sedikit lebih rendah yang terlihat dengan menurunnya fraksi dinding sel (NDF) yang menunjukkan bahwa fraksi iși sel (yang mudah dicerna) menjadi meningkat. Peningkatan dosis urea dalam proses amoniasi ini juga terlihat menurunkan sedikit kandungan lignin. Ini disebabkan urea dalam proses amoniasi akan dirubah menjadi larutan alkali $(\mathrm{NH} 4 \mathrm{OH})$ yang mampu melarutkan sedikit lignin. 
Tabel 1. Pengaruh Dosis Urea Dalam Proses Amoniasi Terhadap Kandungan Protein Bahan Organik Dan Fraksi Serat Daun Sawit (\% BK)

\begin{tabular}{lcccc}
\hline \multirow{2}{*}{ Kandungan } & \multicolumn{5}{c}{ Perlakuan } \\
\cline { 2 - 5 } & $\mathrm{A}$ & $\mathrm{B}$ & $\mathrm{C}$ & $\mathrm{D}$ \\
\hline Bahan Organik & 89,01 & 90,14 & 90,89 & 90,23 \\
Protein kasar & 8,28 & 15,87 & 17,40 & 17,97 \\
NDF & 59,09 & 57,93 & 57,43 & 57,55 \\
ADF & 42,59 & 41,40 & 41,33 & 41,77 \\
Selulosa & 28,85 & 29,04 & 29,60 & 29,80 \\
Hemiselulosa & 16,50 & 16,53 & 16,10 & 16,78 \\
Lignin & 12,28 & 11,53 & 10,68 & 10,72 \\
\hline
\end{tabular}

Keterangan: $\quad \mathrm{A}=$ Daun sawit yang tidak diamoniasi

$\mathrm{B}=$ Daun sawit yang diamoniasi dengan $3 \%$ urea

$\mathrm{C}=$ Serat sawit yang diamoniasi dengan $6 \%$ urea

$\mathrm{D}=$ Serat sawit yang diamoniasi dengan $9 \%$ urea

Tabel 2. Rataan Kecernaan Zat - zat Makanan Perlakuan (\%)

\begin{tabular}{lcc}
\hline Perlakuan & $\begin{array}{c}\text { Kecernaan bahan kering } \\
(\%)\end{array}$ & $\begin{array}{c}\text { Kecernaan bahan organik } \\
(\%)\end{array}$ \\
\hline A & $39,01^{\mathrm{a}}$ & $4737^{\mathrm{a}}$ \\
B & $49,73^{\mathrm{b}}$ & $54,66^{\mathrm{b}}$ \\
$\mathrm{C}$ & $51,31^{\mathrm{c}}$ & $58,61^{\mathrm{c}}$ \\
$\mathrm{D}$ & $52,43^{\mathrm{c}}$ & $60,56^{\mathrm{c}}$ \\
\hline
\end{tabular}

Keterangan : $\quad \mathbf{A}=$ Daun sawit yang tidak diamoniasi

$\mathrm{B}=$ Daun sawit yang diamoniasi dengan $3 \%$ urea

$\mathrm{C}=$ Serat sawit yang diamoniasi dengan $6 \%$ urea

$\mathrm{D}=$ Serat sawit yang diamoniasi dengan $9 \%$ urea

Superskrip dengan huruf yang berbeda menunjukkan perbedaan yang nyata $(\mathbf{P}<0,05)$

\section{Kecernaan Zat-Zat Makanan}

Nilai potensial suatu bahan pakan untuk menyediakan zat - zat makanan tertentu dapat ditentukan dengan analisis kimia, tetapi nilai bahan tersebut bagi ternak hanya dapat ditentukan setelah mengalami kehilangan yang tidak dapat dihindari yang terjadi selama proses pencernaan, penyerapan dan metabolisme ((Mc Donald et al, 1988). Ensminger (1990) menyatakan bahwa ternak tidak dapat memanfaatkan semua zat - zat makanan yang terdapat dalam pakan. Nilai manfaat dari suatu bahan pakan diketahui melalui percobaan penentuan daya cernanya pada ternak, karena analisis kimia hanya menggambarkan nilai suatu pakan tanpa nilai manfaatnya (Anggorodi, 1990; Church dan Pond, 1988).

Pengaruh dosis urea dalam proses amoniasi daun sawit terhadap kecernaan bahan kering dan bahan 
organik (Tabel 2). Hasil analisis ragam memperlihatkan bahwa kecernaan bahan kering dan bahan organik daun sawit amoniasi nyata dipengaruhi oleh dosis urea. Uji lanjut DMRT menunjukkan bahwa peningkatan dosis urea sampai $6 \%$ dari bahan kering daun sawit nyata meningkatkan kecernaan bahan kering dan bahan organik. Peningkatan dosis urea sampai taraf $9 \%$ dari bahan kering (perlakuan D) masih memberikan peningkatan kecernaan tetapi tidak berbeda dengan perlakuan $C$. Tingginya kecernaan pada perlakuan $\mathrm{B}, \mathrm{C}$ dan $\mathrm{D}$ disebabkan fraksi serat dan kandungan lignin dari daun sawit pada perlakuan tersebut cukup rendah dibanding perlakuan A. Hal ini disebabkan urea yang membentuk larutan alkali mempunyai kemampuan untuk merenggangkan ikatan lignoselulosa dan lignohemiselulosa. Akibat merenggangnya ikatan tersebut, lignoselulosa membengkak dan bagian selulosa kristal berkurang dan sedikit lignin dan silika juga akan larut sehingga penetrasi enzim yang dihasilkan mikroba rumen akan lebih sempurna sehingga akan meningkatkan kecernaan yang sejalan dengan hasil penelitian yang didapatkan oleh Wanapat et al, 1982 dan Sundstol, 1991.

Rendahnya kecernaan pada perlakuan A (daun sawit tanpa amoniasi) disebabkan tingginya kandungan lignin dan fraksi serat (NDF dan ADF) dari bahan tersebut. Sesuai dengan pendapat Varga and Hoover (1983) yang menyatakan bahwa tingkat kecernaan berkolerasi negatif dengan kandungan NDF dan ADF bahan.

\section{Kesimpulan}

Dari hasil penelitian dapat disimpulkan bahwa kualitas daun sawit bisa ditingkatkan melalui amoniasi menggunakan urea dan dosis yang optimal dalam peningkatan kecernaan bahan kering dan bahan organik adalah $6 \%$ dari bahan kering daun sawit

\section{Daftar Pustaka}

Anggorodi, R. 1990. Ilmu Makanan ternak Umum. Gramedia, Jakarta

Churh, D.C. and W.G. Ponds. 1988. Basic Animal Nutrition and Feeding. 3nd ed Jhon Willey and Son. New York.

Ensminger, M.E. 1990. Animal Science. The Interstate Printers \& Publisher, Inc. and Ville.

Fauzi, Y, Y.E.Widyastuti. I. Satyawibawa dan R. Hartono. 2006. Kelapa Sawit. Penebar'Swadaya. Jakarta.

Genin, D., T. Khornhani, and M. Hammadi, 2007. Improving nutritive value of North African range grass: Effect of Dung Ash And Urea Treatment On Digestion By Goats. J. Anim. Feed Sci and Technology. Vol. 23. 1-10

Hassan, A.O., and M. Ishida, 1991. Effect of Water, Molasses And Urea Addition On Oil Palm Frond Silage QualityFermentation Characteristic And Palatability to KedahKelantan Bulls. In Proceeding of yhe third International Symposium on the Nutrition 
of Herbivores. Penang. Sundstol, F. 1991. Large Scale Malaysia.

Utilization of Straw for Ruminant Production

Ishida, M., and A.O. Hassan. 1992. Effect of Urea Treatment Level On Nutritive Value of Oil Fronds Silage in KedahKelantan Bulls.In Proceedings of the $6^{\text {th }}$ AAAP Animal Science Congress, Vol 3 AHAT, Bangkok, Thailand, pp.68

Leng, R.A. 1991. Aplication of Biotechnologyto Nutritionof Animalin Developing Countries. FAO Animal Production and Health Paper.

Pomma, S., S, Tuikumpee, A. Ratnavanija, N. Vidyakhorn, and R.W. Froemert, 1985. The effect of urea treated straw on growth and milk production of cross breed Holstein Friesien Dairy Cattle. In The Utilization of Fibrous Agricultural Residues as Animal Feeds. Ed. P.T. Doyle. IDP. Canberra

Steel , R.G.D. and J.H. Torrie. 1980. Principles and Procedure of Statistics. Mc Graw-Hill Book Co.Inc. New York. Systems. In Recent Advances on The Nutrition of Herbivora Ed. Y.W.Ho. H.K.Wong, N. Abdullah, and Z.A. Tajuddin. Malaysia Society of Animal Nutrition.

Tilley, J. M. , and R. A. Terry. 1969. A Two Stage Technique For In Vitro Digestion Of Forage Crops.J. Br. Grassland Society 18 (2): $104-111$

Varga, G.A. and W.H. Hoover. 1983. Rate and extent of NDF of feedstuffs in situ. J. Dairy. Sci. $66: 219$

Van Soest, P.J. 2006. Rice straw the role of silica and treatment to improve quality. J.Anim.Feed. Sci. and Technology Volume 130. 137-171.

Wannapat M.S., S.Praserdsuk, Chatai and Sivapraphagon. 1982. Effect of Rice Straw Utilization Of Treatment With Ammonia Released From Urea And Or Supplementation With Qasava Chips. Paper at the $2^{\text {nd }}$. Annual workshop of the AFAR Research Network 3-7 Mei 1982. UPM. Malaysia

Alamat korespondensi: Dr. Ir. Mardiati Zain M.Sc.

Jurusan Nutrisi Makanan Ternak, Fakultas Peternakan Universitas Andalas, Kampus Limau Manis, Padang Telp. 0751-74208 Fax: 0751-71464

Diterima: 28 Agustus 2007, Disetujui: 24 September 2007 